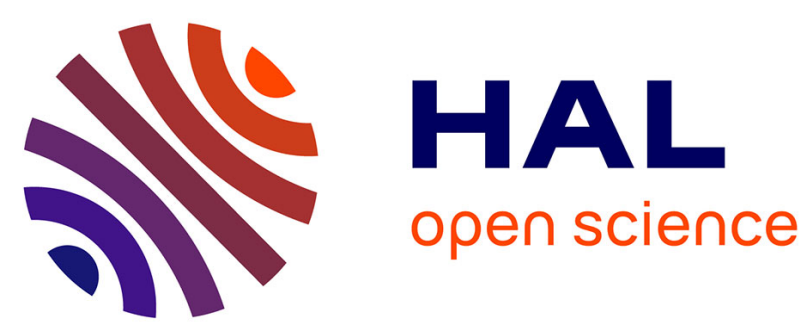

\title{
Unilateral once daily milking locally induces differential gene expression in both mammary tissue and milk epithelial cells revealing mammary remodeling
}

Marion Boutinaud, Laurent Galio, Vanessa Lollivier, Laurence Finot, Sandra Wiart-Letort Wiart, Diane D. Esquerre, Eve Devinoy

\section{To cite this version:}

Marion Boutinaud, Laurent Galio, Vanessa Lollivier, Laurence Finot, Sandra Wiart-Letort Wiart, et al.. Unilateral once daily milking locally induces differential gene expression in both mammary tissue and milk epithelial cells revealing mammary remodeling. Physiological Genomics, 2013, 45 (20), pp.973-985. 10.1152/physiolgenomics.00059.2013 . hal-01004555

\section{HAL Id: hal-01004555 https://hal.science/hal-01004555}

Submitted on 29 May 2020

HAL is a multi-disciplinary open access archive for the deposit and dissemination of scientific research documents, whether they are published or not. The documents may come from teaching and research institutions in France or abroad, or from public or private research centers.
L'archive ouverte pluridisciplinaire HAL, est destinée au dépôt et à la diffusion de documents scientifiques de niveau recherche, publiés ou non, émanant des établissements d'enseignement et de recherche français ou étrangers, des laboratoires publics ou privés. 


\title{
Unilateral once daily milking locally induces differential gene expression in both mammary tissue and milk epithelial cells revealing mammary
}

remodeling

\author{
Marion Boutinaud, ${ }^{2,3 *}$ Laurent Galio, ${ }^{1 *}$ Vanessa Lollivier, ${ }^{2,3,4}$ Laurence Finot, ${ }^{2,3}$ Sandra Wiart, ${ }^{2,3}$ \\ Diane Esquerré, ${ }^{5}$ and Eve Devinoy ${ }^{1}$ \\ ${ }^{1}$ INRA, UR1196 Génomique et Physiologie de la Lactation, Jouy-en-Josas, France; ${ }^{2}$ INRA, UMR1348 PEGASE, Saint-Gilles, \\ France; ${ }^{3}$ Agrocampus Ouest, UMR1348 PEGASE, Rennes, France; ${ }^{4}$ Université européenne de Bretagne, France; and ${ }^{5}$ INRA, \\ UR1313 Génétique Animale et Biologie Intégrative, Jouy-en-Josas, France
}

Submitted 22 April 2013; accepted in final form 26 August 2013

Boutinaud M, Galio L, Lollivier V, Finot L, Wiart S, Esquerré D, Devinoy E. Unilateral once daily milking locally induces differential gene expression in both mammary tissue and milk epithelial cells revealing mammary remodeling. Physiol Genomics 45: 973-985, 2013. First published August 27, 2013; doi:10.1152/physiolgenomics.00059.2013.-Once daily milking reduces milk yield, but the underlying mechanisms are not yet fully understood. Local regulation due to milk stasis in the tissue may contribute to this effect, but such mechanisms have not yet been fully described. To challenge this hypothesis, one udder half of six Holstein dairy cows was milked once a day (ODM), and the other twice a day (TDM). On the 8th day of unilateral ODM, mammary epithelial cells (MEC) were purified from the milk using immunomagnetic separation. Mammary biopsies were harvested from both udder halves. The differences in transcript profiles between biopsies from ODM and TDM udder halves were analyzed by a $22 \mathrm{k}$ bovine oligonucleotide array, revealing 490 transcripts that were differentially expressed. The principal category of upregulated transcripts concerned mechanisms involved in cell proliferation and death. We further confirmed remodeling of the mammary tissue by immunohistochemistry, which showed less cell proliferation and more apoptosis in ODM udder halves. Gene expression analyzed by RT-qPCR in MEC purified from milk and mammary biopsies showed a common downregulation of six transcripts ( $A B C G 2, F A B P 3, N U C B 2, R N A S E 1$ and 5, and SLC34A2) but also some discrepancies. First, none of the upregulated transcripts in biopsies varied in milk-purified MEC. Second, only milk-purified MEC showed significant LALBA downregulation, which suggests therefore that they correspond to a mammary epithelial cell subpopulation. Our results, obtained after unilateral milking, suggest that cell remodeling during ODM is due to a local effect, which may be triggered by milk accumulation.

lactation; mammary epithelial cells; mammary gland microarray

CHANGES IN MILKING FREQUENCY influence milk yield by modulating gene expression in the mammary tissue. Increasing the milking frequency from twice daily (TDM) to four times daily in dairy cattle (18) is associated with alterations both in mammary cell-extracellular matrix interactions and cell signaling, which are mechanisms that contribute to more efficient milk synthesis. By contrast, a reduction in milking frequency to once daily (ODM) induces a decrease in milk protein synthesis as well as an activation of apoptotic signaling networks, which are characteristic of the involution stage (34). The physiolog-

\footnotetext{
* M. Boutinaud and L. Galio contributed equally to this work.

Address for reprint requests and other correspondence: M. Boutinaud, INRA, UMR1348 PEGASE, F-35590 Saint-Gilles, France (e-mail: marion. boutinaud@rennes.inra.fr).
}

ical consequences of ODM are driven by different types of regulation: systemic changes such as the release of hormones [mainly oxytocin and prolactin (PRL)] or local effects due to milk accumulation and modifications in nutrient availability to the mammary gland induced by changes in the mammary blood flow (20).

Autocrine and paracrine effects induced by milk accumulation have been previously reported (29) and demonstrated in animals subjected to unilateral milking. In goats, less frequent milking has been shown to decrease milk yield but only in the udder half less frequently milked (43). In cows, effects induced by an increase in unilateral milking frequency have been studied using transcriptome analyses (54). However, reports on transcriptome modifications after unilateral ODM are scarce.

Transcriptome analyses of the effects of bilateral ODM on cow mammary tissue have clearly shown an induction of apoptotic signaling networks (34). However, to our knowledge, these studies have never been furthered to demonstrate mammary cell apoptosis. By contrast, apoptosis has been studied in goat mammary tissue but inconsistent results were obtained. Indeed, whereas apoptosis was demonstrated in one study (33), two others did not observe apoptosis when examined by terminal deoxynucleotidyl transferase-mediated 2 '-deoxyuridine $5^{\prime}$-triphosphate nick-end labeling (TUNEL) staining (4, 11). Furthermore, it is unknown whether ODM affects mammary cell proliferation. It is therefore important to study the effect of ODM on mammary cell turnover.

From a methodological point of view, studying gene regulations involved in milk synthesis entails the collection of mammary epithelial cells (MEC). A method has been developed that consists of the specific purification of MEC from milk with magnetic beads (10). This method represents an alternative to invasive techniques such as collecting mammary tissues after slaughter or from mammary biopsies. The other major advantage of this method is that it ensures repeated sampling without any carryover effects, thus allowing time course studies in the same animal. However, the use of milkpurified MEC raises a certain number of questions. It has been suggested that milk cells are dead cells and may already be predisposed to apoptosis since they have been ejected into the milk. Moreover a comparison of gene expression in both mammary tissue and milk-purified MEC has only been performed for a small number of genes: essentially coding for milk proteins and stearoyl-CoA desaturase $(\mathrm{SCD})(4,13,25$, 
36). Our previous study showed a downregulation of $\alpha$-lactalbumin $(L A L B A)$ transcripts after ODM in both milk-purified MEC and tissue samples from goats (4).

In the present paper, we investigated a larger gene set through the use of microarrays and real-time RT-PCR (RTqPCR) after unilateral ODM vs. TDM in dairy cows and analyzed the networks of genes displaying variations in expression. The effects of ODM on mammary cell turnover were also evaluated. In addition, we compared the results from milk-purified MEC and mammary tissue to test whether milkpurified MEC transcriptome variations might enable the prediction of ODM effects on the mammary gland.

\section{MATERIALS AND METHODS}

Animals and experimental design. All the procedures applied to animals were approved by the Animal Care Committee of the French Ministry of Agriculture, in accordance with French regulations (decree no. 2001-464, May 26, 2001).

Six Holstein cows at different stages of lactation [45 days in milk (DIM), $n=2 ; 120$ DIM, $n=2$ and 320 DIM, $n=2$ ] and with different lactation ranks $(\operatorname{rank} 1, n=1 ; \operatorname{rank} 2, n=3$ and $\operatorname{rank} 4, n=$ 2) were used in this study. Two of the rank 2 cows were between 27 and 45 days of pregnancy, while the others were not pregnant. We selected these cows because of their well-balanced milk yield between the udder halves. The cows were milked twice daily as from the onset of lactation. During $1 \mathrm{wk}$ prior to the initiation of treatment (pretreatment period), each udder half was milked separately to determine the level of milk production, which was $15.4 \pm 1.0 \mathrm{~kg}$ of milk per udder half per day. The cows were then subjected to a differential milking frequency that consisted in unilateral once (in the morning)- and TDM for 8 days.

The cows were housed at the INRA Méjusseaume experimental dairy farm (UMR1348, IEPL, Le Rheu, France). They were fed ad libitum according to INRA guidelines with a diet containing $65 \%$ corn silage, $7 \%$ alfalfa silage, $17 \%$ supplement, and $1.4 \%$ mineral supplement on a dry matter basis. Feed intakes were recorded daily during the pretreatment and treatment periods and did not vary.

During the pretreatment and differential milking periods, milk production was measured individually by udder half at each milking, 5 days/wk. Milk samples were collected from the right and left glands of each cow, at each milking, 5 days/wk. The fat and protein content of milk samples collected during the morning and afternoon milkings was determined using an infrared method (Lillab, Châteaugiron, France). Milk lactose was analyzed by means of a colorimetric enzymatic reaction (kit for lactose/D-galactose; Roche, Meylan, France) via a multiparameter analyzer (Kone Instruments, Espoo, Finland).

Milk epithelial cell preparation. On the 8th day of differential milking frequency, milk samples were collected at morning milking from both udder halves for MEC purification, as previously described (10). In brief, $5.6 \mathrm{~kg}$ of fresh milk was centrifuged at $1,500 \mathrm{~g}$ for 15 min at $4{ }^{\circ} \mathrm{C}$. The fat layer and skimmed milk were discarded, and the cell pellet was retained. The cell pellet was suspended in phosphatebuffered saline (PBS). After two washes in PBS, the cell pellet was resuspended in $3 \mathrm{ml}$ PBS containing $1 \%$ bovine serum albumin (BSA). We counted $10 \mu \mathrm{l}$ of this cell suspension with a hematocytometer (VWR International, Fontenay sous Bois, France) under light microscopy to determine the total milk cell count. A $450 \mu \mathrm{l}$ volume of magnetic beads (Pan Mouse IgG, Dynal Biotech; Invitrogen, Cergy Pontoise, France) was incubated with $9 \mu$ lanti-cytokeratin- 8 antibody (clone K8.13; Sigma-Aldrich Chimie, Lyon, France) in $1 \mathrm{ml} \mathrm{1 \%}$ PBS-BSA. Each cell sample was incubated with $150 \mu$ l of the bead/antibody mix described above. After $1 \mathrm{~h}$ of incubation, the samples were placed in a magnetic particle concentrator (MPC-S, Dynal Biotech, Invitrogen) and the supernatant containing nonse- lected cells was removed. The purified MECs were resuspended in 1 $\mathrm{ml}$ of $1 \%$ PBS/BSA. A $20 \mu \mathrm{l}$ aliquot of purified cell suspension was collected for the hematocytometer cell count of purified MEC. The collection of $5.6 \mathrm{~kg}$ of milk enabled the preparation of $8.4 \pm 2.0 \times$ $10^{6}$ purified MEC, which represented $11 \pm 3 \%$ of the total milk cells prepared. The remaining MECs were pelleted by centrifugation ( 5 min, $4^{\circ} \mathrm{C}, 5,000 \mathrm{~g}$ ) and $1 \mathrm{ml}$ of Trizol (Invitrogen) was added. The lysates were stored at $80^{\circ} \mathrm{C}$ until RNA extraction.

Mammary biopsies. Mammary biopsies were collected from both udder halves after the morning milk collection on day 8 of the differential milking frequency period. Biopsies were collected from the upper portion of the mammary gland, as previously described (3). Briefly, before the tissue biopsy, local anesthesia was applied through the SC injection of $40 \mathrm{mg}$ Xylocain (Astra France, Rueil-Malmaison, France). The biopsies were performed with a disposable $12 \mathrm{G} / 10 \mathrm{~cm}$, $22 \mathrm{~mm}$ Bard Monopty core biopsy instrument (Laboratoires Bard, Voisins le Bretonneux, France). The skin incision was closed with a disposable skin stapler (Royal 35W; Clinique Vétérinaire, St Grégoire, France). The cows then received an injection of antibiotic (Excenel im; Pfizer Sante Animale, Paris, France).

The mammary tissue was rinsed in sterile saline solution. Three 20 $\mathrm{mg}$ biopsies were frozen in liquid nitrogen and stored at $-80^{\circ} \mathrm{C}$ until they were used for RNA extractions. Another biopsy sample was washed in PBS (Fisher Scientific Bioblock) and fixed for $24 \mathrm{~h}$ in $4 \%$ paraformaldehyde (Sigma-Aldrich) for immunohistochemistry. The fixed tissue was incubated for $48 \mathrm{~h}$ in a $40 \%$ sucrose solution (Sigma-Aldrich), embedded in Tissue-Tek O.C.T. Compound (Sakura Finetek Europe, LaboNord, Templemars, France), frozen in a cooled bath of isopentane (Sigma-Aldrich), and stored at $-80^{\circ} \mathrm{C}$ until use. Histological analyses were performed on each mammary biopsy.

RNA extraction. RNA was extracted with Trizol from both milkpurified epithelial cells and mammary biopsies and then purified using the column from the RNeasy Minikit (Qiagen, Courtaboeuf, France) according to the manufacturer's recommendations, including the DNase digestion. The RNA pellet was suspended in RNase-free water, and the amount of total RNA determined with an Agilent 2100 bioanalyzer (Agilent Technologies, Massy, France). RNA quality was assessed by using the RNA integrity number (RIN) generated by version B.02 of Agilent 2100 Expert Software (Agilent Technologies). The amounts of RNA recovered from the mammary biopsies of two cows were small; although one sample (early lactation) could still be used for transcriptome analyses, the second one (midlactation) was not included in any of the analyses. One sample of total RNA obtained from milk-purified MEC (from the other early lactating cow) did not meet our quality control criteria; it was removed from the RT-qPCR analyses of milk-purified MEC. The RNA selected from mammary tissue and milk-purified MECs had high RIN (RIN $=8.5 \pm 0.07$ and $7.0 \pm 0.49$, respectively, for mammary tissue and milk MEC).

Microarray, probe labeling, and array hybridization. A $22 \mathrm{k}-\mathrm{ele}-$ ment bovine oligoarray [National Center for Biotechnology Information Gene Expression Omnibus (GEO): GPL6694] was used to determine and compare the transcript profiles between biopsies from the ODM and TDM mammary glands of five cows. The $22 \mathrm{k}$ chip produced by the French National CRB GADIE platform is a combination of the bovine $8.7 \mathrm{k}$ oligonucleotide set from Operon and the $13.2 \mathrm{k}$ oligonucleotide set designed by the Illinois University spotted on Corning UltraGAPS aminosilane slides using a Chipwriter (Virtek). We converted $20 \mu \mathrm{g}$ of each RNA sample into amino-allyllabeled cDNA with oligo-dT primers, amino-allyl-dUTP (Sigma, Saint-Quentin-Fallavier, France), and superscript II Reverse Transcriptase (Invitrogen). The resulting cDNA was purified on a Microcon PCR column according to the manufacturer's protocol (Millipore, St-Quentin-en-Yvelines, France), and an aliquot of fluorescent dye (Cy3 or Cy5; GE HealthCare, Velizy, France) was added. Unused reactive sites were blocked by $4 \mathrm{M}$ hydroxylamine, and fluorescent probes were purified on QiaQuick columns according to the manufacturer's recommendations (Qiagen). All probes were quantified 
using a Nanodrop ND-1000 spectrophotometer (NanoDrop Technologies, Wilmington, DE). The Cy3 and Cy5 probes were then combined in equal proportions according to their fluorescence intensity (in pmol), denatured for $2 \mathrm{~min}$ at $95^{\circ} \mathrm{C}$, and cohybridized on the $22 \mathrm{k}$ oligoarray at $42^{\circ} \mathrm{C}$ for $16-18 \mathrm{~h}$ with the Pronto! Universal Microarray Kit (Corning, Bagneaux-sur-Loing, France) according to the manufacturer's recommendations. After stringent washes to remove unbound cDNA, the slides were scanned with an Agilent scanner (Agilent Technologies), and the features were analyzed with Agilent quantification software (Agilent Technologies). Under this experimental design, each mammary biopsy RNA sample from one udder half was compared on the same slide, with that of the contralateral udder half, thus minimizing animal variability. Dye-swaps were performed for each animal.

Microarray data analysis. Data were normalized by a global LOESS regression $(48,58)$ followed by a subtraction of the median by block and analyzed with a mixture model that identifies clusters of genes with equal variance (21) using the "anapuce" R package (http://www.r-project.org/). Statistically significant raw $P$ values were adjusted for multiple comparisons using the Benjamini-Hochberg procedure that controls the false discovery rate (FDR) (7), which was set at 0.05. Differentially expressed genes (DEG) were analyzed with Ingenuity Pathway Analysis software (IPA: http://www.ingenuity. com, release 5.5) to classify the DEG according to their Gene Ontology biological process, identify significant differences in biological functions, and distribute the DEG into canonical pathways or networks.

$R T-q P C R$. Total RNA from milk-purified epithelial cells and mammary tissue were used for RT-qPCR analyses. The samples from four and five cows were analyzed by RT-qPCR for milk-purified MEC and mammary biopsy, respectively. Complementary DNA was obtained with the First Strand cDNA kit (Promega, Lyon, France) according to the manufacturer's instructions, from $500 \mathrm{ng}$ of total RNA (with the exceptions of $250 \mathrm{ng}$ for the two mammary biopsies from one cow and $350 \mathrm{ng}$ for two milk epithelial cell samples from another).

Real-time PCR (qPCR) was performed using Syber Green Master Mix (Applied Biosystems, Villebon sur Yvette, France), according to the manufacturer's instructions. In brief $12.5 \mathrm{ng}$ cDNA were mixed with 6 pmol of all forward and reverse primers and adjusted to 12.5 $\mu \mathrm{l}$ with Syber Green Master Mix and $10 \mu \mathrm{l}$ DNase-free water (see Table 1). The qPCR amplification cycle was composed of 2 min of incubation at $50^{\circ} \mathrm{C}$ followed by denaturation for $10 \mathrm{~min}$ at $95^{\circ} \mathrm{C}$ and

Table 1. Bovine primers used for qPCR analyses

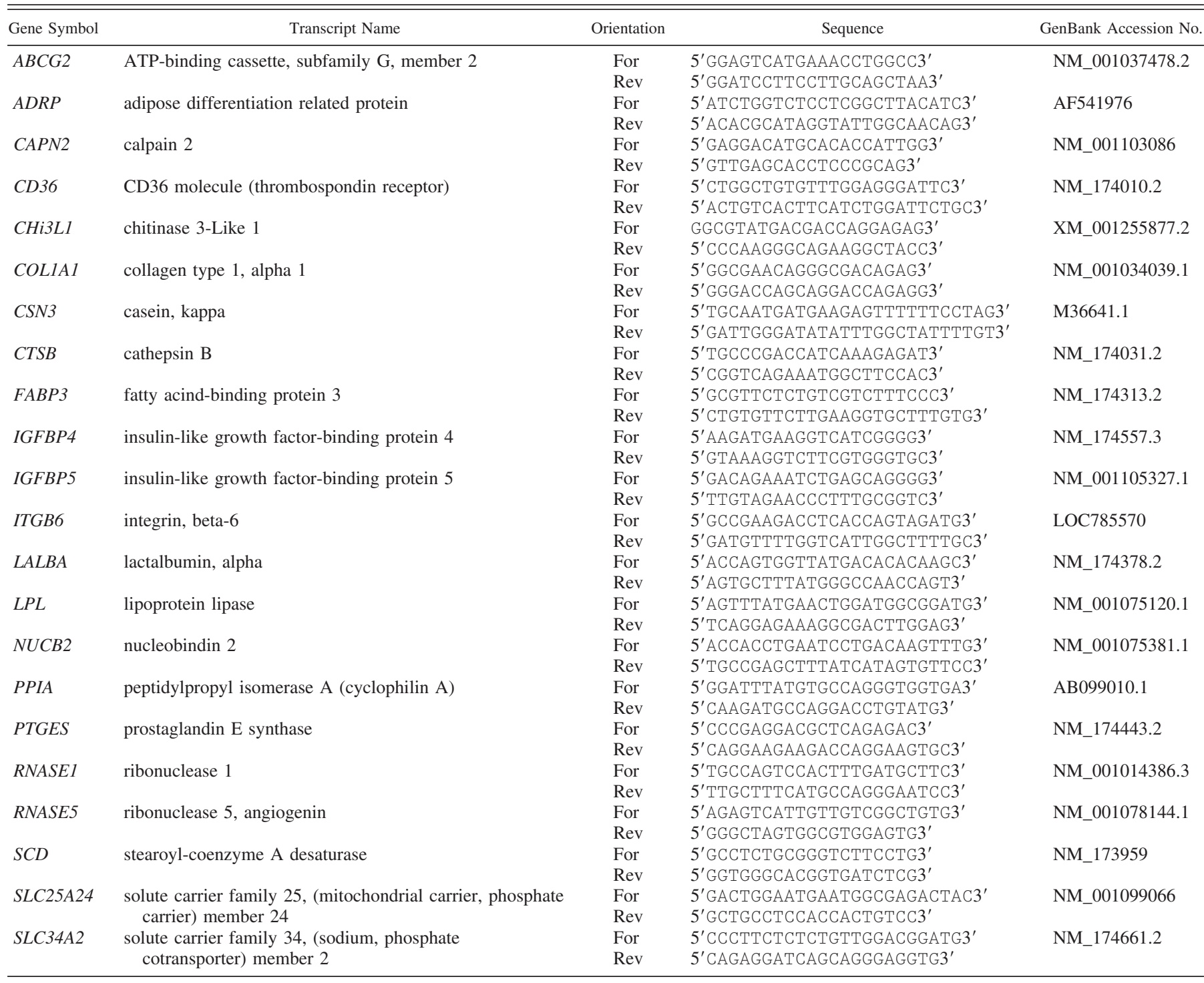

For, forward; Rev, reverse. 
40 cycles of denaturation for $15 \mathrm{~s}$ at $95^{\circ} \mathrm{C}$ and anneal/extension for 60 $\mathrm{s}$ at $60^{\circ} \mathrm{C}$. Finally, a dissociation step was performed, involving a linear increase of $1{ }^{\circ} \mathrm{C} / \mathrm{min}$ from $60^{\circ} \mathrm{C}$ to $95^{\circ} \mathrm{C}$ with continuous fluorescence acquisition. The qPCR reactions on each sample were performed in triplicate. PCR amplifications were performed using the primers for cyclophilin, $L A L B A$, and $\kappa$-casein (CSN3), as previously described (10). For the other genes analyzed during this study, the primers were designed from bovine mRNA sequences using PrimerExpress (2.0) software (Applied Biosystems, Foster City, CA) or an oligo support team (Sigma Aldrich). When the exon/intron sequences of the genes were available, the primers were designed to hybridize on different exons to prevent genomic DNA amplification.

$m R N A$ quantification. The number of amplified mRNA molecules was determined as previously described (14), according to the following formula:

$\mathrm{Nb} \mathrm{Mol}=10^{\wedge}(\mathrm{Ct}-40) / \mathrm{S}$, where $\mathrm{Nb} \mathrm{Mol}=$ approximate number of mRNA molecules, $\mathrm{Ct}=$ the average cycle threshold for PCR triplicates of a considered gene, and $\mathrm{S}=$ the slope of the calibration curve performed using serial cDNA dilutions of the same sample.

The calibration curves were generated for each target and housekeeping gene using serial dilutions of a reference mammary tissue cDNA sample from a lactating cow (1:10, 1:20, 1:50, 1:100, 1:200, $1: 1,000$, and $1: 2,000)$. A nontemplate negative control was incorporated in all PCR runs.

The cyclophilin, $\beta$-actin, r18S, and glyceraldehyde-3-phosphate dehydrogenase genes were evaluated as potential reference genes. The BestKeeper (40), GeNorm (52), and NormFinder (1) programs were used to assess the variability of candidate reference genes. Cyclophilin was the gene with the most stable expression and was therefore used as the reference gene during this study. The results for each target gene are expressed as a ratio using the selected reference gene, namely cyclophilin.

Immunohistochemistry. Apoptotic cells were quantified in mammary gland biopsies by the detection of DNA fragmentation by TUNEL. Cryosections measuring $7 \mu \mathrm{m}$ thick and mounted on slides treated with 3-minopropyltriethoxysilane (Sigma-Aldrich) were thawed and incubated for $30 \mathrm{~min}$ at $70^{\circ} \mathrm{C}$ in a $10 \mathrm{mM}$ citrate sodium (Sigma-Aldrich) $0.1 \%$ Triton solution (Fisher Scientific Bioblock), washed in PBS, and incubated for $30 \mathrm{~min}$ at $37^{\circ} \mathrm{C}$ in $200 \mathrm{ng} / \mu \mathrm{l}$ proteinase $\mathrm{K}$ solution (Promega). The tissue sections were incubated with DeadEnd Fluorometric TUNEL System (Promega) reagents, according to the manufacturer's instructions.

Proliferating mammary cell were identified as cells expressing the proliferating cell nuclear antigen (PCNA). Cryosections measuring 7 $\mu \mathrm{m}$ thick were mounted on Superfrost/Plus slides (Prolabo, Bondoufle, France). Mammary gland sections were quenched in PBS with $3 \%$ hydrogen peroxide and $10 \%$ methanol for $30 \mathrm{~min}$. After several PBS washes, the sections were permeabilized in PBS with $1 \%$ SDS for $5 \mathrm{~min}$, washed three times in PBS, and incubated for $1 \mathrm{~h}$ in PBS with $1 \% \mathrm{BSA}$ at room temperature. Incubation with anti-PCNA antibody (M0879, DakoCytomation) overnight at $4^{\circ} \mathrm{C}$ was then performed. After primary antibody incubation, the tissue sections used for PCNA labeling were washed in PBS with $1 \%$ BSA and incubated with 1:200 diluted secondary antibody (F5387, goat anti-mouse FITC conjugated antibody, Sigma-Aldrich) for $1 \mathrm{~h}$ at room temperature. They were then washed three times in PBS with $1 \%$ BSA.

After TUNEL staining or PCNA labeling, the sections were incubated for 3 min with 4',6-diamidino-2-phenylindole (DAPI, SigmaAldrich) at a concentration of $0.33 \mu \mathrm{g} / \mathrm{ml}$. All slides were mounted with Vectashield (Valbiotech, Paris, France) and examined under fluorescence using a Nikon Eclipse E400 microscope (Nikon France, Le Pallet, France). The images were captured with a DXM 1200 digital still camera (Nikon) and analyzed with the ImageJ software (Wayne Rasband; National Institutes of Health, Bethesda, MD). Eight microscopic fields (magnification, $\times 200$; area, $0.14 \mathrm{~mm}^{2}$ per microscopic field) were examined for both the right and left glands. The percentages of apoptotic and proliferating cells in both glands were determined as a ratio between the TUNEL or PCNA-labeled cells and DAPI-counterstained nuclei. For each acinus, the ImageJ software was used to count the number of cells and determine alveolar size. Immunohistological analyses confirmed that the biopsy samples had indeed been collected from the secreting mammary parenchyma.

Determination of milking-induced PRL release. To determine PRL release, a silastic catheter (Silclear medical-grade silicone tubing, inner diameter $1.02 \mathrm{~mm}$, outer diameter $2.16 \mathrm{~mm}$; Degania Silicone, Degania Bet, Israel) was inserted into the jugular vein of each cow. Jugular blood samples were collected 2 days before and 5 days after the beginning of the unilateral ODM treatment. Samples were taken over AM milking, when both udder halves were milked, at $-2,0,1$, $2,4,10$, and 16 min relative to milking machine attachment, using Monovette syringes coated with sodium heparin (Sarstedt, Nümbrecht, Germany). Plasma was separated by centrifugation at $4^{\circ} \mathrm{C}$ and $3,000 \mathrm{~g}$ for $15 \mathrm{~min}$ and then stored at $-20^{\circ} \mathrm{C}$ for subsequent analysis. Plasma PRL concentrations were measured with an indirect competitive ELISA (31). Intra-assay variability was $<2 \%$, and inter-assay variability was $<12 \%$. The basal PRL concentration was determined as PRL concentration in plasma before milking machine attachment, the PRL peak concentration as the maximum PRL concentration in plasma during the first 16 min following milking machine attachment, the variation in PRL concentration (PRL delta) as the difference between peak and basal values. We calculated the amounts of PRL released into the blood at milking by determining the areas under the curves of PRL concentration during the first 16 min following milking.

Statistical analyses. Individual day milk data were analyzed by ANOVA using the SAS MIXED procedure (SAS Institute 1999) with REPEATED statements. Days were used as a repeated effect and cow (milking frequency) as the subject. The data obtained during the pretreatment period were averaged and used as a covariate per udder half. The effects of milking frequency, day, lactation stage, animal (lactation stage), as well as the interaction between milking frequency and day and the interaction between lactation stage and milking frequency, were tested. PRL data and immunohistochemical data were analyzed by ANOVA using the SAS MIXED procedure (SAS). The effects of milking frequency, lactation stage, animal (lactation stage), and the interaction between lactation stage and milking frequency, were tested. Statistical analysis of qPCR data was performed on the semiabsolute mRNA molecule number of the target gene/reference gene ratio multiplied by $10^{4}$ and $\log 10$ transformed. The effects of milking frequency on qPCR data was analyzed with a paired Student's $t$-test. Effects were considered to be significant at $P<0.05$.

\section{RESULTS}

Milk production and composition and determination of milking-induced prolactin release. Six Holstein cows with wellbalanced daily production per udder half were subjected to unilateral ODM and TDM for 8 days. As expected, daily milk production from udder halves milked once daily was on average reduced by $31 \%(P=0.002)$ compared with TDM udder halves (Table 2). This reduction in milk yield ranged from 25 to $40 \%$, depending on the cows and depending on the lactation stage $(P=0.07)$. During ODM vs. TDM, the decrease in milk yield was lower for the late lactating cows compared with the early or midlactating cows (14.0 vs. $20.4,10.9$ vs. 16.2 , and 10.7 vs. $14.7 \mathrm{~kg}$ of milk per day for early, mid-, and late lactation cows, respectively). The decrease in milk yield was associated with significant reductions in the amounts of protein, fat, and lipid produced per day. The reduction in milk lactose yield $(32 \%, P=0.001)$ was more pronounced than that of total milk yield due to a lower milk lactose content in ODM udder halves $(P=0.02)$. Milking-induced PRL release was 
Table 2. Milk yield and composition in the udder halves of cows milked unilaterally ODM or TDM

\begin{tabular}{lcccccc}
\hline \hline & ODM & TDM & SE & MF & Stage & MF $\times$ Stage \\
\hline Milk, kg/day & 11.9 & 17.1 & 0.15 & 0.002 & 0.13 & 0.07 \\
Fat content, g/kg & 38.3 & 36.8 & 0.67 & 0.26 & 0.09 & 0.30 \\
Protein content, g/kg & 32.8 & 32.5 & 0.19 & 0.39 & 0.45 & 0.42 \\
Lactose, g/kg & 48.2 & 50.3 & 0.23 & 0.02 & 0.23 & 0.29 \\
Fat yield, g/day & 439 & 591 & 11.5 & 0.01 & 0.38 & 0.42 \\
Protein yield, g/day & 377 & 531 & 6.6 & 0.004 & 0.27 & 0.25 \\
Lactose yield, g/day & 575 & 845 & 11.3 & 0.004 & 0.67 & 0.12 \\
\hline
\end{tabular}

Data are presented as means $\pm \mathrm{SE} ; n=6$. Data were analyzed by ANOVA using the SAS MIXED procedure with REPEATED statements. Days used as a repeated effect and cows (milking) used as the subject. The data obtained during the pretreatment period were used as a covariate; the effects of milking frequency (MF), day, stage of lactation and the interaction between MF and day, and MF and lactation stage were tested. ODM, once daily milking; TDM, twice daily milking.

monitored 2 days before and during the unilateral ODM treatment. The amount of PRL release, its peak concentration, and the difference between peak and basal concentrations were similar after unilateral ODM $(P \geq 0.35)$ and during TDM (Table 3). Interestingly, the amount of PRL release and its peak concentration were reduced as lactation proceeds $(P=0.07$ and $P=0.03$, respectively), whereas the PRL basal concentration was not significantly modified. No interaction was observed between changes in milking frequency and the stage of lactation for PRL data.

Differences in the transcriptome profiles of mammary biopsies from ODM vs. TDM udder halves. The transcriptome analyses were performed using a dye swap design by hybridizing cDNAs obtained from mammary biopsies collected from both udder halves in five different cows after 8 days of differential milking frequency, on bovine $22 \mathrm{k}$-oligonucleotide microarrays. The data are available on the GEO database (GEO ID: GSE43505).

Between ODM and TDM, statistical analysis revealed that, out of the 22,000 transcripts present on the microarray, 490 or 1,021 were differentially expressed with an FDR threshold set at 0.05 or $<0.1$, respectively. However, the 531 transcripts detected with the less stringent FDR did not add much in terms of family of transcripts. Some other members of the milk protein gene family such as the CNSISI, CNS3, and LALBA were then detected. When the ODM udder halves were compared with contralateral halves, with an FDR inferior to 0.05, 222 , and 268 of these transcripts were up- and downregulated, respectively. The 40 most up- and downregulated transcripts are listed in Table 4. As the array includes both the $8.7 \mathrm{k}$ set from Operon and a 13.2k set (Illinois University), some redundancy was observed among the probes. As a consequence, some transcripts appear twice in Table 4: CH13L1, KRT5, $B M F$, and $R B P 1$ (upregulated transcripts), $A B C G 2, C D 36$, CIDEA, DNAJC12, FABP3, GP2, SCD, SLC31A2, SLC34A2 (downregulated transcripts), showing that the two sets of probes generated consistent results.

Family of transcripts. IPA performed on all DEG revealed 22 biological function categories of DEG after ODM vs. TDM (Fig. 1). Most of the families revealed by IPA are related to cellular events such as cell cycle, cellular growth and proliferation (ABCG2, FABP3, KRT8), cell death (BMF, IGFBP5, $C T S B)$, and cellular development (CEBPD, CLU, ITGB6). The transcripts of these families were mostly upregulated (in $>60 \%$ of cases). Another category of transcripts is involved in the metabolism of the mammary epithelium, such as small molecule biochemistry (PAH, PTGES, RBPI), lipid (SCD, CD36, $F A B P 3, L P L)$, carbohydrate (GPAM, Chi3L1), and amino acid metabolism (SLC25A24, PAH), and molecular transport $(S L C 34 A 2, A T P 2 C 2, R B P 1)$. Transcripts belonging to this second category were mostly downregulated (in $>67 \%$ of cases). The third category concerns transcripts expressed in nonepithelial mammary tissue, such as ERBB3 described in adipocytes, endothelial, and immune cells; EFNA from the hematological system; ITGB6 and IGFBP4 from the inflammatory system; and COLIAI and LUM from the connective tissue. Most of these transcripts were upregulated (in $>67 \%$ of cases). Two examples of two networks were visualized with the Ingenuity Systems software (Fig. 2, $A$ and $B$ ). The lipid metabolism network clearly show that numerous genes involved in lipid synthesis were differentially expressed in the mammary tissue and that they were mainly downregulated (42 vs. 19). One main connecting point in this network was the gene that encodes a transcription factor, SREBF1. The other network presented (Fig. 2B) was a construction assembling the three main cellular and molecular top functions produced by the Ingenuity Systems software, which were cellular growth and proliferation, cell movement, and cell death. Most of the genes in this network were upregulated (55 vs. 40). The main connective points for the upregulated genes were $E R B B 3, F N 1$, RAC, EGR1, JUNB, ATF3, MAP3K1, SDC1, KRT18, IGFBP5, and $C A S P 7$. The role of some of these connective points in the mammary tissue has been already described. For example, ERBB3 is a receptor whose activation leads to cell proliferation or differentiation, known to be frequently overexpressed in a context of human breast cancer, required for mammary morphogenesis, and its expression varies as a function of the

Table 3. PRL concentration and milking-induced PRL release (AUC) in the plasma of cows before differential MF, during $T D M$ and unilateral $O D M / T D M$

\begin{tabular}{|c|c|c|c|c|c|c|c|c|c|c|}
\hline & \multicolumn{3}{|c|}{ ODM/TDM } & \multicolumn{3}{|c|}{ TDM } & $\mathrm{SE}$ & \multicolumn{3}{|c|}{$P$} \\
\hline AUC & $35,800^{\mathrm{a}}$ & $14,600^{\mathrm{ab}}$ & $23,700^{\mathrm{ab}}$ & $33,900^{\mathrm{a}}$ & $13,800^{\mathrm{ab}}$ & $6,100^{\mathrm{b}}$ & 8,160 & 0.35 & 0.07 & 0.55 \\
\hline Delta, $\mathrm{ng} / \mathrm{ml}$ & 47.5 & 29.8 & 36.0 & $61.2^{\mathrm{a}}$ & 21.7 & $18.4^{\mathrm{b}}$ & 15.51 & 0.76 & 0.20 & 0.61 \\
\hline Basal, ng/ml & 45.5 & 43.0 & 32.0 & 47.0 & 58.0 & 44.5 & 11.63 & 0.35 & 0.60 & 0.83 \\
\hline
\end{tabular}

$n=6$. Basal, prolactin (PRL) concentration in plasma before milking machine attachment; peak, maximum PRL concentration in plasma during the first 16 min following milking machine attachment; delta, difference between peak and basal values; AUC, area under the curve of PRL concentration in plasma during the first 16 min following milking; stage, stage of lactation. a, b for significant difference $(P<0.05)$; a', b' for a tendency for a difference $(P<0.10)$. 
Table 4. List of the 40 most upregulated and downregulated transcripts in the MG after unilateral ODM vs. TDM, including the names of the oligonucleotides (oligo ID) given on the microarrays

\begin{tabular}{|c|c|c|c|}
\hline Oligo ID & HUGO & $\begin{array}{c}\text { Fold } \\
\text { Change }\end{array}$ & $\begin{array}{l}P \text { Value } \\
\text { BH }\end{array}$ \\
\hline \multicolumn{4}{|c|}{ Upregulated by $O D M$} \\
\hline Bt00007310 & CHI3L1 & 4.4 & 0.03 \\
\hline OLIGO_12367 & CHI3L1 & 3.5 & 0.02 \\
\hline OLIGO_10377 & $C T S B$ & 2.7 & 0.02 \\
\hline Bt00006868 & $C L U$ & 2.6 & 0.02 \\
\hline OLIGO_01576 & KRT5 & 2.5 & 0.02 \\
\hline OLIGO_11338 & KRT8 & 2.4 & 0.01 \\
\hline Bt00007304 & KRT5 & 2.1 & 0.03 \\
\hline Bt00000906 & SAP3OL & 2.1 & 0.02 \\
\hline OLIGO_12501 & NMESI and pri-bta-miR-147 & 2.1 & 0.03 \\
\hline OLIGO_00879 & $B M F \dagger$ & 2.0 & 0.05 \\
\hline OLIGO_10636 & TPM4 & 2.0 & 0.01 \\
\hline OLIGO_11084 & COL1A1 & 2.0 & 0.03 \\
\hline OLIGO_10748 & $I G F B P 5$ & 2.0 & 0.01 \\
\hline Bt00007379 & $R B P 1$ & 2.0 & 0.01 \\
\hline Bt00003008 & EFNA1 & 1.9 & 0.02 \\
\hline OLIGO_10638 & $R B P 1$ & 1.9 & 0.02 \\
\hline OLIGO_11110 & $P R P H$ & 1.9 & 0.01 \\
\hline OLIGO_04552 & $S O D 2 *$ & 1.9 & 0.02 \\
\hline Bt00006169 & S100A11 & 1.8 & 0.02 \\
\hline Bt00006908 & KRT7 & 1.8 & 0.02 \\
\hline OLIGO_02239 & $A R R D C 4 \dagger$ & 1.8 & 0.04 \\
\hline OLIGO_11528 & $C E B P D$ & 1.8 & 0.04 \\
\hline Bt00006764 & PTGES & 1.8 & 0.01 \\
\hline OLIGO_12200 & CYB561 & 1.8 & 0.04 \\
\hline OLIGO_12161 & ITGB6 & 1.8 & 0.01 \\
\hline OLIGO_04743 & $K L F 6 \dagger$ & 1.7 & 0.03 \\
\hline OLIGO_08510 & S100A14 & 1.7 & 0.02 \\
\hline OLIGO_09322 & LYPD3 & 1.7 & 0.02 \\
\hline OLIGO_02248 & LUM & 1.7 & 0.03 \\
\hline Bt00008272 & COTL1 & 1.7 & 0.03 \\
\hline Bt00007747 & EGR1 & 1.7 & 0.04 \\
\hline OLIGO_11289 & TACSTD $2 \dagger$ & 1.7 & 0.04 \\
\hline OLIGO_11536 & $T I M P 2 \dagger$ & 1.7 & 0.03 \\
\hline Bt00005902 & $B M F \dagger$ & 1.7 & 0.03 \\
\hline OLIGO_07711 & CLIC1 & 1.7 & 0.02 \\
\hline OLIGO_10940 & $\begin{array}{l}\text { ZNF644; BAP1; FTL; ALPK2; PAK2; } \\
\quad \text { SLBP }\end{array}$ & 1.7 & 0.03 \\
\hline OLIGO_10381 & LGALS1 & 1.7 & 0.04 \\
\hline OLIGO_13133 & ERBB3 & 1.7 & 0.02 \\
\hline Bt00002432 & CNN1 & 1.7 & 0.02 \\
\hline OLIGO_12104 & IGFBP4 & 1.7 & 0.03 \\
\hline \multicolumn{4}{|c|}{ Downregulated by ODM } \\
\hline OLIGO_12806 & SLC16A1 & 0.5 & 0.03 \\
\hline OLIGO_00612 & TNRC6C & 0.5 & 0.02 \\
\hline OLIGO_00144 & CUL9 & 0.5 & 0.04 \\
\hline OLIGO_11443 & GALM & 0.4 & 0.02 \\
\hline OLIGO_02635 & RASSF4 & 0.4 & 0.02 \\
\hline Bt00008070 & SEP15† & 0.4 & 0.05 \\
\hline OLIGO_12257 & CSN2 & 0.4 & 0.05 \\
\hline OLIGO_12420 & $G P 2 \dagger$ & 0.4 & 0.02 \\
\hline OLIGO_10408 & NSFL1C & 0.4 & 0.03 \\
\hline Bt00000290 & SLC31A2 & 0.3 & 0.01 \\
\hline OLIGO_12216 & MUC15 & 0.3 & 0.03 \\
\hline OLIGO_08804 & SLC31A2 & 0.3 & 0.0001 \\
\hline OLIGO_06803 & $R N A S E 5^{*}$ & 0.3 & 0.01 \\
\hline Bt00006820 & $A D R P$ & 0.3 & 0.04 \\
\hline Bt00007291 & $X D H$ & 0.3 & 0.02 \\
\hline OLIGO_12148 & $S L C 34 A 2$ & 0.3 & 0.04 \\
\hline Bt00006834 & $L R P P R C$ & 0.3 & 0.05 \\
\hline Bt00004528 & ТОРЗВ & 0.3 & 0.01 \\
\hline OLIGO_10837 & CIDEA & 0.3 & 0.01 \\
\hline
\end{tabular}

Table 4.-Continued

\begin{tabular}{llccc}
\hline \hline \multicolumn{1}{c}{ Oligo ID } & & HUGO & $\begin{array}{c}\text { Fold } \\
\text { Change }\end{array}$ & $\begin{array}{c}P \text { Value } \\
\text { BH }\end{array}$ \\
\hline Bt00006997 & PAH & & 0.2 & 0.03 \\
OLIGO_11970 & CABP1 & 0.2 & 0.03 \\
Bt00001328 & ATP2C2 & 0.2 & 0.01 \\
Bt00003831 & THOC5 & 0.2 & 0.03 \\
OLIGO_09278 & DNAJC12 & 0.2 & 0.04 \\
OLIGO_12312 & RNASE1 & 0.2 & 0.03 \\
OLIGO_11868 & CD36 & 0.2 & 0.01 \\
OLIGO_01142 & FASN & 0.2 & 0.03 \\
Bt00002026 & SLC34A2 & 0.2 & 0.02 \\
OLIGO_13062 & GPAM & 0.2 & 0.02 \\
Bt00007511 & ABCG2 & 0.2 & 0.02 \\
Bt00007235 & CIDEA & 0.2 & 0.03 \\
Bt00006951 & ABCG2 & 0.2 & 0.02 \\
OLIGO_05822 & CD36 & 0.2 & 0.0001 \\
Bt00007331 & GP2 & 0.2 & 0.01 \\
Bt00007059 & DNAJC12 & 0.2 & 0.01 \\
OLIGO_11285 & SCD $\dagger$ & 0.2 & 0.01 \\
Bt00007029 & SCD $\dagger$ & 0.2 & 0.01 \\
Bt00007314 & LPL & 0.1 & 0.01 \\
Bt00006728 & FABP3 & 0.1 & 0.0001 \\
OLIGO_10660 & FABP3 & 0.1 & 0.0001 \\
\hline
\end{tabular}

Statistically significant raw $P$ values were adjusted for multiple comparisons by the Benjamini-Hochberg $(\mathrm{BH})$ procedure, which controls the false discovery rate. $\dagger$ Oligos whose sequence relates to a sequence flanking the $3^{\prime}$-end of the gene annotation in UMD3.1. *Oligos whose sequence relates to an intron of the gene annotation in UMD3.1. MG, mammary gland.

stage of mammary development in rodents $(19,27)$. FN1 is involved in cell adhesion and migration and is known to modulate cell proliferation and induce matrix metalloproteinase (MMP) activity in the mammary tissue $(46,55)$. The principal connective points for the downregulated genes in this network were NFKB1, EAPS1, and SREBF1. NFKB1 is a transcription factor whose inhibition leads to delayed cell growth; it is activated during mastitis, and its activation during involution results in a reduction in milk yield (17). EPAS1 is a catabolic transcription factor induced by hypoxia which can induce the expression of MMPs (57) and promote angiogenesis (23). Analyses of the connective point produced evidence of key regulator genes that were not always strongly regulated (and are not included in Table 4, showing the 40 most regulated genes).

No clear up- or downregulation of DEG related to markers of luminal epithelial cells (cytokeratins 8 and 18, MUC1 and 15, and sialomucin), myoepithelial cells (cytokeratins 5, 14, and 17, vimentin, nestin, and desmin), endothelial cells (EPAS1, PECAM1, EDF1, EDG2, and ESM1), leukocytes (CD45, CD96, Cd5, and CD81, CD53, CD51), and adipocytes (Pref-1, APMAP) has been observed in this study. The average values for the five cows tend to indicate that variation in cell populations is not a key factor in our study.

Variations in the expression of 21 differently expressed transcripts were further studied with an RT-qPCR approach. These genes were chosen because of more marked variations in their expression between udder halves and their associated biological functions. Two other transcripts (CSN3 and LALBA) that are strongly expressed in the mammary gland during lactation were also included in this analysis.

Comparison of mRNA levels between mammary biopsies from $O D M$ vs. TDM by RT-qPCR. The expression of most genes in the mammary tissue, analyzed by RT-qPCR or microarrays, 


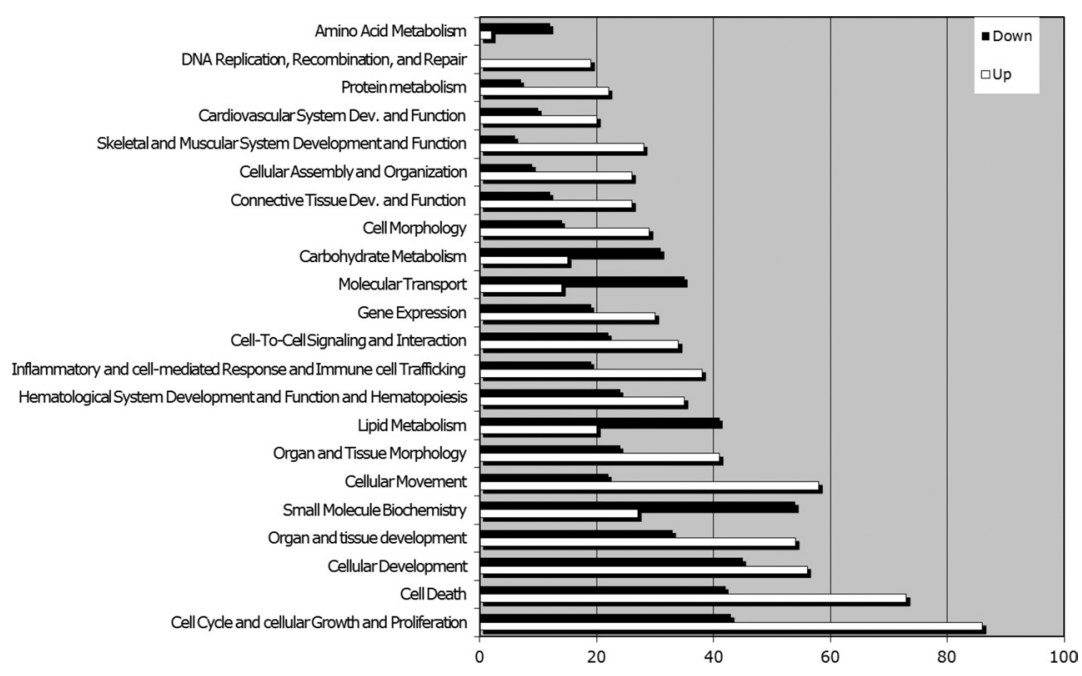

Fig. 1. Number of transcripts upregulated (white boxes) or downregulated (black boxes) in once daily milked (ODM) vs. twice daily milked (TDM) udder halves in each ontological category of the major molecular functions. The ontology was determined with Ingenuity Systems software.

varied in the same way as a function of milking frequency. For four transcripts (COL1A1, IGFBP4, SLC25A24, CAPN2) we observed a significant upregulation with ODM in both microarray and RT-qPCR analyses, whereas for four other transcripts (CTSB, IGFBP5, ITGB6, PTGES), and even though the expression levels detected by RT-qPCR were higher after ODM (Table 5), they did not differ significantly. Four transcripts (RNASE5, RNASE1, CD36, FABP3) were significantly downregulated by ODM in both microarray and RT-qPCR analyses. Six others, downregulated under microarray analysis, were only numerically and not significantly downregulated when evaluated by RT-qPCR (NUCB2, ADRP, SCD, ABCG2, SLC34A2, and LPL; $P<0.2$ ). A trend toward the downregulation of LALBA and CSN3 transcripts in microarray analysis was only also observed for LALBA with RT-qPCR analysis $(P \leq 0.10)$. Altogether, RT-qPCR analyses confirmed microarray data.

Comparison of mRNA levels between milk-purified MEC and mammary biopsies. Biopsy sampling is a surgical procedure that requires a local anesthesia, induces some bleeding, and is only performed with the agreement from the ethical committee. This technique also produces samples that may display variations depending on where they have been collected from the mammary tissue. Biopsies should therefore be checked by microscopy to ensure their content in epithelial tissue. We therefore tried to determine whether milk-purified MEC, a less invasive method, might be representative of some of the variations observed in tissue biopsy findings. mRNA levels were estimated by RT-qPCR in both milk-purified MEC and mammary biopsies from ODM and TDM udder halves and were analyzed after corrections with respect to cyclophilin transcripts.

RT-qPCR analyses showed that in most cases, the transcripts downregulated by ODM in biopsies (listed in Table 5) were also downregulated in milk-purified MEC. Six of the 10 transcripts downregulated in mammary biopsies (microarray analysis) were also significantly downregulated in milk-purified MEC (NUCB2, RNASE5, ABCG2, RNASE1, SLC34A2, $F A B P 3)$. Interestingly, $L A L B A$ was significantly downregulated in milk-purified MEC but only tended to be downregulated under both types of mRNA analyses in mammary biopsies. By contrast, three of the transcripts that were significantly downregulated in mammary tissue (microarray analyses) were clearly not modified by ODM in milk-purified MEC (ADRP, $C D 36, L P L, P>0.6)$. In addition, none of the nine transcripts upregulated in mammary tissue were significantly modified by ODM in milk-purified MEC. Moreover, two of them (CHI3L1 and $P T G E S)$ tended to be downregulated by ODM $(P=0.11$ and 0.10 , respectively). The comparison of $\mathrm{mRNA}$ variations after ODM between milk-purified MEC and mammary biopsies shows some discrepancies that have been further analyzed.

Immunohistological analysis of cell proliferation and apoptosis. Mammary biopsies exhibited transcript variations related to tissue remodeling. We therefore performed immunohistological analyses to search for any variations in specific markers for tissue remodeling.

Analyses of cell turnover in the mammary gland were performed on tissue sections from mammary biopsies collected after 8 days of differential milking frequency. The percentage of proliferating cells in the mammary gland evaluated as cells positive for PCNA (Fig. 3), relative to nuclei positive for DAPI, was lower in ODM udder halves than in controlateral glands $(-26 \%, P=0.04$, Fig. $3 E$ ). The level of apoptosis in the mammary tissue determined using TUNEL assay was higher in ODM udder halves $(+65 \%, P \leq 0.01$, Fig. $4 E)$. These effects were not associated with a significant change in the size of alveoli, which averaged 6,880 and 4,530 $\pm 1,670$ $\mu \mathrm{m}^{2}(P=0.37, n=12)$ for the ODM and the contralateral glands, respectively. Interestingly, lactation stages and the interaction between milking frequency and lactation stage had no significant effect on the size of alveoli (data not shown, $P=$ 0.54 and 0.48 , respectively). A greater variation between ODM udder halves might explain why differences between the ODM and TDM udders were not significant even though marked differences in diameter were observed.

\section{DISCUSSION}

The three main families of DEG observed between ODM udder halves and their controlateral glands, revealed by IPA, are related to cell remodeling (cell cycle, cellular growth and proliferation, cell death, and cellular development). These families were also found to be the top three canonical functions (cell death, cancer, and cellular movement) that were eluci- 


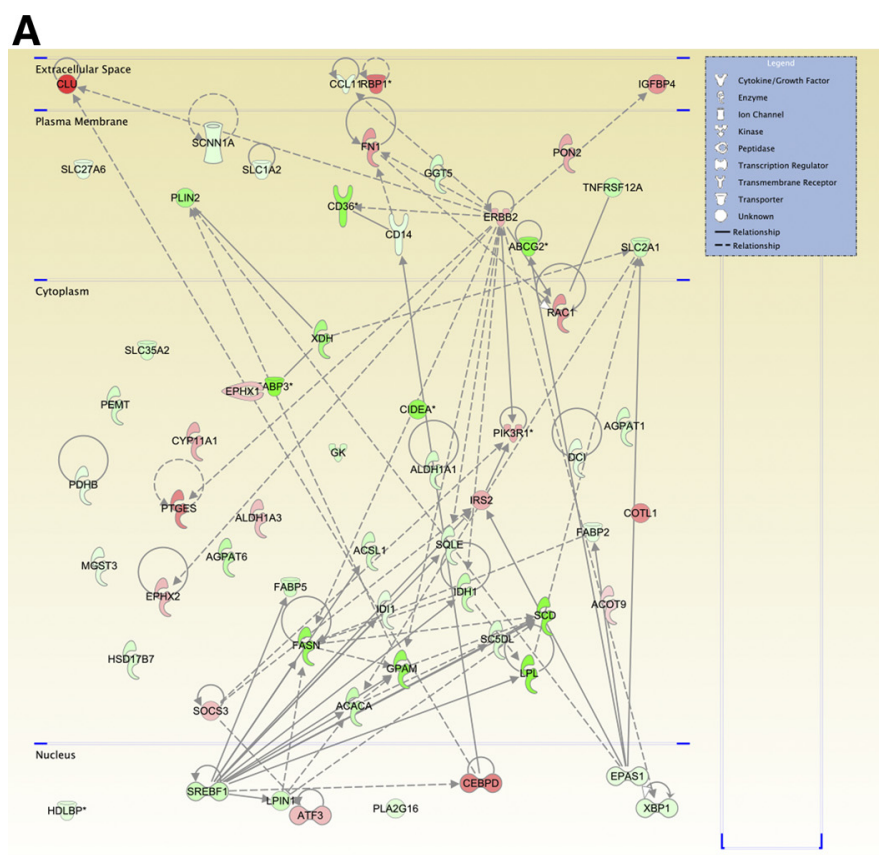

B

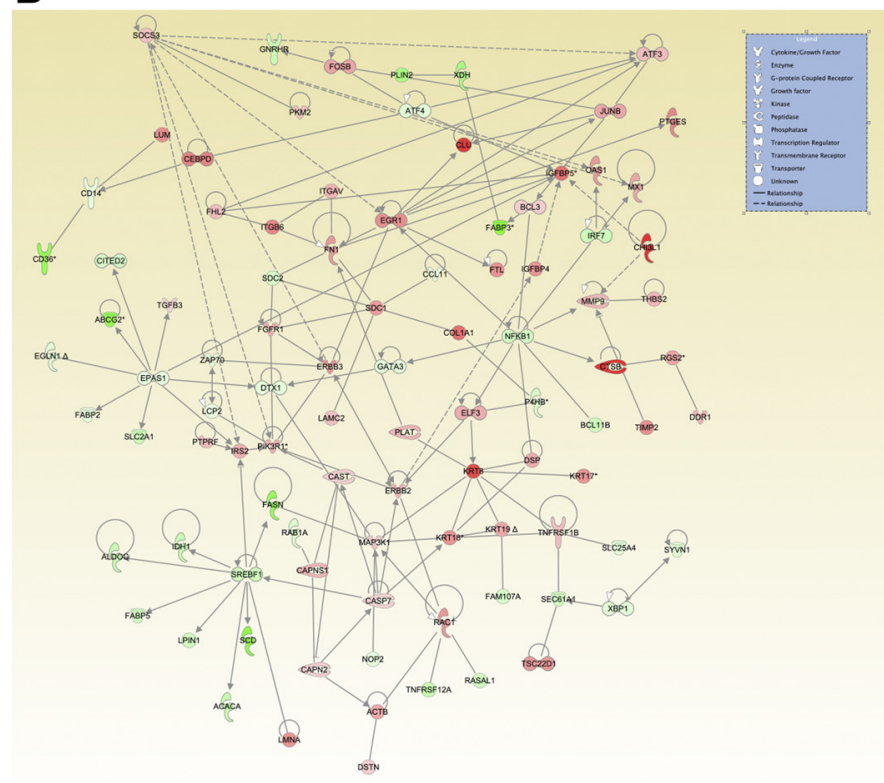

Fig. 2. Top gene networks associated with the expression changes observed in ODM udder halves vs. TDM halves and highlighted in Table 4 and Fig. 1. $A$ : lipid metabolism network. $B$ : cellular movement and cell death network. This analysis was generated by Ingenuity Systems software (http://www. ingenuity.com).

dated by microarray analyses as gene expression changes associated with a sequential reduction in milking frequency from twice daily to once daily for 5 days in dairy cows (34). Some of the transcripts described by Littlejohn et al. (34) as being genes involved in cell remodeling (IGFBP5, ERBB3, PTGES, ATF3, JUN, NFKB, KRT8, KRT7, CD36, and GPAM) were also differentially expressed in our study. The originality of our study was that ODM and TDM were simultaneously applied to the cows (by unilateral milking) and that we further investigated cell death and proliferation through immunohis- tological analyses. Our results clearly demonstrated changes in cell turnover in the mammary tissue after unilateral ODM, with an enhancement of cell apoptosis and a reduction of cell proliferation. To our knowledge, this is the first study to have really enabled in situ observation of the induction of cell death in the bovine mammary gland after ODM. Our findings are in line with those obtained in unilaterally ODM udder halves vs. three time milked halves in goats (33). In the present study, the effects of unilateral ODM during 8 days on cell turnover were not accompanied by changes to alveolar size in contrast with the effect of unilateral ODM during 24 days observed in goat (15). These unexpected results can be explained by the fact that these regimens were only applied for a short period as opposed to 24 days. Similar immunohistological results (induction of apoptosis and lower proliferation) have been observed in goat udders in which milk accumulated unilaterally for $36 \mathrm{~h}$ (6). These effects also corresponded to the physiological changes that occur in the bovine mammary gland during mammary involution. Previous microarray analyses reveal that involution is the result of multistage mechanisms implicating hundreds of genes involved in metabolism, apoptosis and proliferation, immune response and inflammation, oxidative stress, and tissue remodeling. $(41,47,49)$. The upregulation of CEBPD, $T G F B 3$, and IGFBP5 and the downregulation of $A B C G 2 \mathrm{ob}-$ served in ODM udder halves compared with TDM udder halves has been previously demonstrated as being part of the early stage of mammary involution $(22,24,49)$. The cell remodeling and cell turnover changes observed after 8 days of

Table 5. Comparison of mRNA levels in half MG or milk $M E C$ of cows milked unilaterally ODM compared with the TDM contralateral udder half

\begin{tabular}{|c|c|c|c|c|c|c|}
\hline \multirow{2}{*}{$\begin{array}{c}\text { Gene } \\
\text { Symbol }\end{array}$} & \multicolumn{2}{|c|}{$\begin{array}{c}\text { Microarray Data for } \\
\text { MG }\end{array}$} & \multicolumn{2}{|c|}{ RT-qPCR for MG } & \multicolumn{2}{|c|}{$\begin{array}{c}\text { RT-qPCR for Milk } \\
\text { MEC }\end{array}$} \\
\hline & ODM/TDM* & $P \dagger$ & ODM/TDM* & $P \ddagger$ & ODM/TDM* & $P \ddagger$ \\
\hline CHi3L1 & 3.5 & 0.02 & 4.2 & 0.12 & 0.6 & 0.11 \\
\hline$C T S B$ & 2.7 & 0.02 & 1.6 & 0.08 & 0.6 & 0.36 \\
\hline COLIA1 & 2 & 0.03 & 1.9 & 0.05 & 0.6 & 0.64 \\
\hline IGFBP5 & 2 & 0.01 & 1.9 & 0.07 & 0.6 & 0.51 \\
\hline$I T G B 6$ & 1.8 & 0.01 & 1.6 & 0.09 & 0.8 & 0.41 \\
\hline PTGES & 1.8 & 0.01 & 1.4 & 0.07 & 0.6 & 0.10 \\
\hline$I G F B P 4$ & 1.7 & 0.03 & 2.4 & 0.03 & 0.6 & 0.52 \\
\hline SLC25A24 & 1.6 & 0.01 & 2 & 0.003 & 0.8 & 0.74 \\
\hline CAPN2 & 1.3 & 0.05 & 2.1 & 0.005 & 0.7 & 0.41 \\
\hline$N U C B 2$ & 0.6 & 0.01 & 0.6 & 0.13 & 0.6 & 0.03 \\
\hline RNASE5 & 0.3 & 0.01 & 0.2 & 0.01 & 0.5 & 0.002 \\
\hline$A D R P$ & 0.3 & 0.04 & 0.3 & 0.06 & 0.8 & 0.64 \\
\hline$S C D$ & 0.2 & 0.01 & 0.3 & 0.18 & 0.6 & 0.19 \\
\hline$A B C G 2$ & 0.2 & 0.02 & 0.2 & 0.12 & 0.5 & 0.02 \\
\hline RNASE1 & 0.2 & 0.03 & 0.05 & 0.002 & 0.3 & 0.03 \\
\hline SLC $34 A 2$ & 0.2 & 0.02 & 0.1 & 0.14 & 0.4 & 0.05 \\
\hline CD36 & 0.2 & 0.01 & 0.3 & 0.01 & 0.8 & 0.64 \\
\hline$F A B P 3$ & 0.1 & 0.01 & 0.03 & 0.05 & 0.5 & 0.03 \\
\hline$L P L$ & 0.1 & 0.01 & 0.2 & 0.13 & 1 & 0.94 \\
\hline$L A L B A$ & 0.6 & 0.09 & 0.001 & 0.10 & 0.3 & 0.05 \\
\hline CSN3 & 0.2 & 0.06 & 0.02 & 0.16 & 0.5 & 0.12 \\
\hline
\end{tabular}

Fold changes were evaluated with a microarray $(n=5$ for MG) and RT-qPCR [ $n=4$ for MG and $n=5$ for mammary epithelial cells (MEC)]. The top section corresponds to upregulated levels of expression and the bottom part to downregulated levels of expression. Validation of microarray results via qRT-PCR analysis and qRT-PCR in milk MEC. *Results displayed as fold changes as compared with TDM. †Bonferroni adjusted significance criterion. $\ddagger$ The effects of milking frequency on qPCR data were analyzed by a paired Student's $t$-test. 

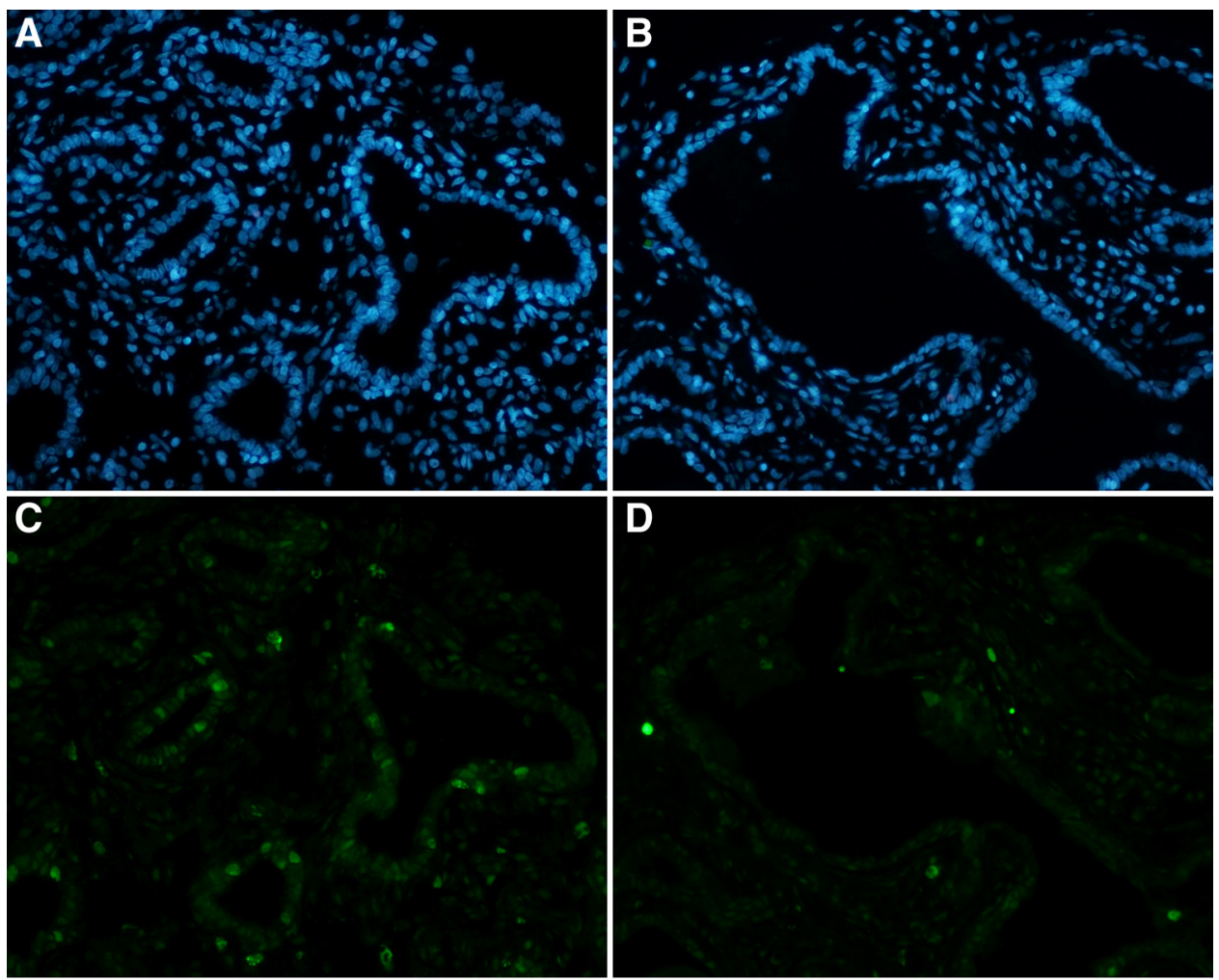

Fig. 3. Detection of cell proliferation in cow mammary tissue from ODM or TDM udder halves $(n=6)$. The mammary tissue sections from TDM $(A$ and $C)$ or ODM $(B$ and $D$ ) udder halves were stained simultaneously with 4',6-diamidino-2-phenylindole (DAPI) $(A$ and $B$ ) and proliferating cell nuclear antigen (PCNA) antibody $(C$ and $D)$. The micrographs present the sections obtained in udder halves from 1 representative cow (magnification $\times 200$ ). The percentages of cells in proliferation were evaluated in each case $(E)$. The ODM udder halves displayed a significantly lower level of proliferation than TDM halves, as confirmed by Student's $t$-test after $\log$ transformation $(* P<0.04)$. Data are

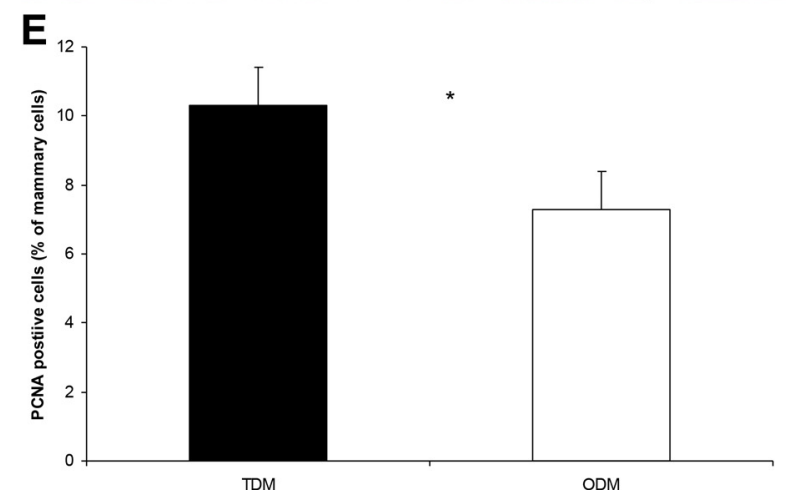
presented as least-square means $\pm \mathrm{SE}$.

unilateral ODM therefore correspond to the first stage of mammary gland involution.

Although there are numerous similarities in gene expression changes between the unilateral ODM study and bilateral ODM (34), the two experimental designs differ from a hormonal point of view. During our study, ODM and TDM were performed on the same animal, and our data tend to show that this differential milking affects neither plasma PRL concentrations nor milking-induced PRL release. However, further studies with a higher number of animals should be performed to confirm this result. Nevertheless, both udder halves were subjected to the same systemic PRL environment. Therefore, the effects of unilateral ODM on the modification of mRNA profiles and cell turnover are mainly due to a local effect and are not likely to be a consequence of modifications to milkinginduced PRL release. Because unilateral ODM caused effects similar to those of bilateral ODM (34), we were able to conclude that the local effect of milk accumulation was the principal effect during ODM, whether this was unilateral or bilateral. Nevertheless, the inhibition/activation of PRL release in cows have similar cellular targets. Indeed, the inhibition of milking-induced PRL release, already described in dairy cows (30), can also modify cell turnover and cell activity (12). Moreover, transcriptome analyses performed on mouse mammary glands and $\mathrm{HC} 11$ cells after PRL treatments revealed that a certain number of modulated genes are similar to those described in our study [SCL34A2, ALDO3, CTSC, SLC35A2, ERRB2, SQLE, CEBPD, SCD, ANGPT14 (37)]. This common regulation may have been due to the upregulation of SOCS3, already mentioned as being downregulated during four-timesdaily milking or treatment with PRL (53), which is known to inhibit JAK2 activity, one of the main downstream pathways of PRL signaling, or the downregulation of Stat5 activity as already observed after unilateral ODM. In turn, inhibition of the JAK2/STAT5 pathway may be responsible for the downregulation of $A B C G 2$ since this pathway is involved in the induction of $A B C G 2$ by PRL in T-47D human breast cancer cells (56). Comparing unilateral and bilateral ODM can allow one to distinguish effects locally induced by milk accumulation vs. ones induced by the inhibition of systemic 
Fig. 4. Detection of apoptotic cells in cow mammary tissue from ODM or TDM udder halves $(n=6)$. The mammary tissue sections from TDM ( $A$ and $C$ ) or ODM ( $B$ and $D$ ) udder halves were stained simultaneously $(C$ and $D)$. The micrographs present the sections obtained in udder halves from 1 representative cow (magnification $\times 400$ ). The percentages of apoptotic cells were evaluated in each case $(E)$. The ODM udder halves displayed a significantly higher level of apoptosis than TDM halves, as confirmed by Student's $t$-test after $\log$ transformation $(* * P<0.001)$. Data are presented as leastsquare means $\pm \mathrm{SE}$. with DAPI $(A$ and $B$ ) and TUNEL assay
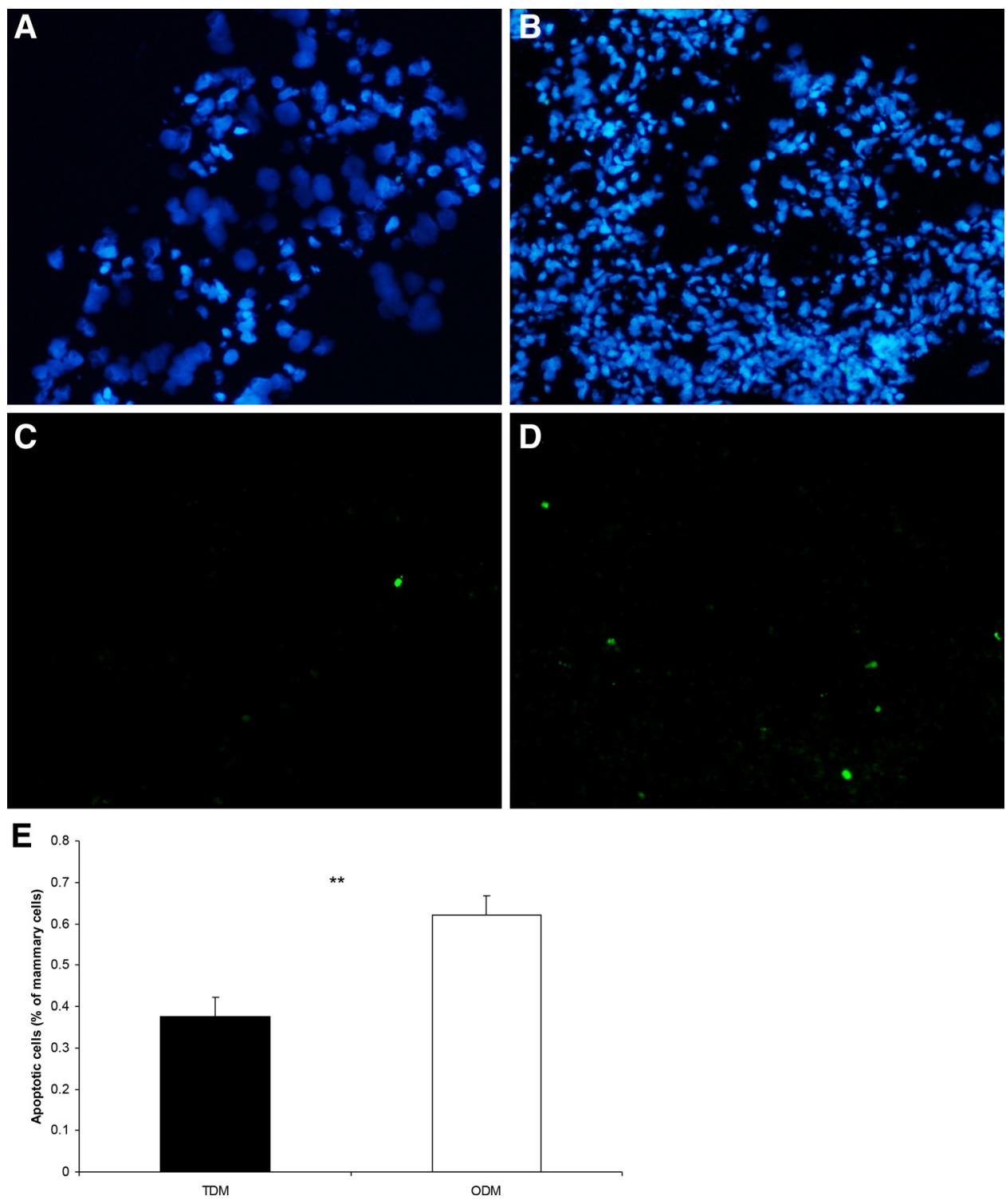

PRL release. However, as similar cellular changes were observed in the mammary gland, leading to a decrease in milk yield with both unilateral and bilateral ODM, we conclude that the local effect of milk accumulation plays a major role during both treatments.

Numerous hypotheses have been advanced to explain the local effects of milk accumulation. It may result from the feedback inhibition of lactation and/or a physical effect due to milk accumulation or some combination thereof (29). Such local effects have been found to be responsible for modifications in tight junction openings that were studied after unilateral $36 \mathrm{~h}$ milk accumulation (6). Indeed, increased intramammary pressure during milk engorgement, stretching the mammary epithelium, may be responsible for activating the mechanoreceptors that generate intracellular apoptotic signals. At the same time, the disruption of cell junctions may initiate a cell unhooking process in the mammary epithelium, leading to a loss of cell communication with the extracellular matrix and neighboring cells, which is known to induce apoptosis (42). In ODM udder halves, the upregulation of genes such as
MMP9 and TIMP2 (involved in the regulation of metalloprotease activity and degradation of the extracellular matrix) suggests mammary gland remodeling similar to that which occurs during mammary gland involution $(44,59)$. Moreover, several transcripts belonging to the cellular assemblage and organization family and from the extracellular matrix were differentially expressed, such as COL1A1, KRT8, KRT5, KRT7, $L U M$, and MUC15. These genes have also been described as being differentially expressed after an increase in milking frequency $(18,54)$. It is probable that modifications to cell remodeling to adjust milk production to the new milking frequency (leading to a reduction in the number of cells in the mammary gland) requires the remodeling not only of MEC but also of all mammary tissue, as was also indicated by the third category of transcripts that were differentially expressed in our study, i.e., those linked to nonepithelial mammary tissue (hematological system, inflammatory system, connective tissue, and cardiovascular system). Thus cell remodeling in mammary tissue after unilateral ODM involves gene modifications in all types of mammary cells. 
It is important to note that among all the families thus regulated, lipid metabolism was one of the most downregulated. This important effect could be explained by the fact that lipid metabolism is dependent on numerous proteins for its regulation, by comparison with protein production, which is directly linked to messenger transcription and translation. Most of the steps in milk fat metabolism were represented among the downregulated transcripts: fatty acid uptake ( $L P L$ and $C D 36)$, fatty acid and cholesterol transport (FABP2, FABP3, FABP5, and $A B C G 2$ ), fatty acid synthesis and saturation (FASN, $S C D$, $A C A C A$ ), and also key regulators of triacylglycerol synthesis [LPN1 and AGPAT6 (51)]. The principal connecting point in this lipid network, also downregulated, is the gene that encodes a transcription factor, SREBF1, which is known to be central to the regulation of milk fat synthesis (8). These downregulations are also observed during mammary involution (41). During the present study, downregulations of the lipid metabolism network were in accordance with a decrease in total milk fat production. Our results supply some more information on the effect of ODM on milk fat content, which remains controversial in the literature. Most studies have demonstrated an increase in milk fat content $(32,38)$, whereas other studies have reported no variation $(35,45)$, as in our study, or a decrease (5) in the milk fat content during ODM. These discrepancies may be due to a time-dependent regulation of milk fat content due to variations in milk fat synthesis involving a large set of genes, as observed in the present study.

The comparison of gene expression in milk-purified MEC and mammary biopsies with respect to 21 transcripts analyzed by RT-qPCR revealed some discrepancies between the mammary tissue and milk-purified MEC. These discrepancies are probably not due to an effect of the treatment on mRNA quality of milk-purified MEC as opposed to a recent study (2), since we carefully selected RNA samples with the required quality. Although our study was initially designed to minimize physiological variability throughout lactation (for a review see Ref. 9; two animals sampled at each stage of lactation, i.e., early, mid-, and late lactation), the distribution of RNA samples per stage of lactation was not respected since we were unable to obtain sufficient total RNA of good quality from all six cows and all three RNA analytical methods. For these reasons, variations due to lactation stage could not be ruled out.

The discrepancies and similarities of RNA expression between mammary tissue RNA and milk-purified MEC may have biological relevance. First, our study suggests that milk-purified MEC can predict ODM effects on the mammary gland, as similar variations are observed in both milk-purified MEC and mammary tissue regarding five transcripts coding for proteins that are mainly involved in milk secretion, such as FABP3, a fatty acid transporter; ABCG2, a carrier-associated secretion of xenobiotics; SLC34A2, a solute carrier; and RNASE5 and RNASE1, antimicrobial agents. In addition, NUCB2 [which has recently been found to be involved in cell proliferation and migration in human MEC (50)] was similarly downregulated in both mammary tissue and milk-purified MEC. These results suggest that milk-purified MEC may be representative of mammary tissue MEC, in which transcription of genes controlling cell proliferation is downregulated when milk production is decreased. However, a significant downregulation of $L A L B A$ transcripts in milk-purified MEC, which was consistent with previous studies in cows $(10,12)$ and goats $(4,5)$, was observed in mammary tissue only with the less stringent FDR microarray analyses. The analyses of milk-purified MEC may prevent any interference between the quantification of MEC gene expression and that of other cell types (myoepithelial cells, endothelial cells, and adipocytes) present in the biopsies. Such interferences have recently been observed in dairy cows, where the effects of inhibiting milking-induced PRL release were more significant in milk-purified MEC than in mammary biopsies (12). By contrast, biopsy sampling enabled the performance of other analyses (e.g., immunohistological) that were useful to further characterize mammary cell remodeling during unilateral ODM in cows. Second, the comparison of gene expression between the mammary gland and milk-purified MEC provides further indications regarding the effects of ODM in the mammary gland. The levels of three genes involved in milk fat synthesis ( $L P L, C D 36$, and $A D R P)$ did not vary in milk-purified MEC, whereas they were markedly downregulated in the mammary biopsies. These RNA correspond to three proteins that are not epithelial cell-specific but are also expressed in other cells that form the mammary tissue such as fibroblasts, endothelial cells, smooth muscle cells, and macrophages $(16,26,61)$. In monocytes/macrophages, CD36 is involved in phagocytosis and the clearance of apoptotic cells (60), while ADRP plays a key role in macrophage foam cell formation during early atherogenesis (39). Downregulation of their expression in mammary tissue may be located in monocytes/macrophages and, therefore, not related to a reduction in milk fat synthesis but related to increased levels of apoptosis level in this tissue, as a feedback effect after 8 days of unilateral ODM. Surprisingly, we were not able to observe any transcript that was upregulated in milk-purified MEC and particularly those involved in one of the principal families expressed differentially between ODM and TDM, which is cell remodeling (cellular growth and proliferation, cell movement, and cell death). This can be explained for some transcripts by the fact that they belong to a category linked to nonepithelial mammary tissue, transcripts that in theory are not detected in milk-purified MEC and weakly expressed in the milk-purified MEC samples (such as ITGB6 and IGFBP4 in the inflammatory system or COLIAI in the connective tissue). In contrast, the absence of variations in other transcripts coding for proteins involved in cell death, such as IGFBP-5 known to be expressed in a mouse MEC cell line (14), tends to indicate that milk-purified epithelial cells correspond to a subpopulation of MEC. Indeed, different subpopulations of MEC were recently described in the mammary tissue (28). Milk-purified MEC could correspond to a late secretory type of MEC, and further studies are required to reveal if they would correspond to dying secretory cells. Thus the analyses neither of milk-purified MEC nor those of the mammary tissue are fully representative but may be complementary approaches by which to study the effects of unilateral ODM.

\section{Conclusion}

Transcriptome and immunohistological analyses revealed that one of the principal physiological processes that occurs in mammary tissue after unilateral ODM is cell remodeling, which corresponds to the early stages of mammary gland involution. The reduction in milk yield induced by unilateral ODM milking is also associated with a decrease in the tran- 
scripts involved in milk fat metabolism. The effect of unilateral ODM was found to be similar to that of bilateral ODM, demonstrating that local milk accumulation is an important event during ODM. Our results highlight ODM-induced active mammary remodeling that could persist throughout lactation and even during subsequent lactations. Epigenetic studies are now in progress to unravel the long-term effects of milking frequency on subsequent milk production.

\section{ACKNOWLEDGMENTS}

The authors thank P. Lamberton and the "Physio team" at Méjusseaume (INRA, UMR1348, IEPL, Le Rheu, France), for taking care of the cows and for assistance with milk and plasma sampling. We are also grateful to J. Portanguen and S. Marion for technical help, to F. Faucon for assistance with statistical analyses, and to the staff at the ICE facility (INRA UMR1313 GABI, Jouy-en-Josas, France) for providing access to transcriptomic tools.

\section{GRANTS}

This research received financial support from INRA and the APISGENE/ ANR project "GENOMILK FAT," coordinated by P. Martin (INRA, Jouy-enJosas) and K. Duhem (CNIEL, Paris).

\section{DISCLOSURES}

No conflicts of interest, financial or otherwise, are declared by the author(s).

\section{AUTHOR CONTRIBUTIONS}

Author contributions: M.B., L.G., and E.D. conception and design of research; M.B., L.G., L.F., S.W., and D.E. performed experiments; M.B., L.G., V.L., and E.D. analyzed data; M.B. and L.G. interpreted results of experiments; M.B. and L.G. prepared figures; M.B., L.G., and E.D. drafted manuscript; M.B., L.G., V.L., and E.D. edited and revised manuscript; M.B., L.G., V.L., L.F., S.W., D.E., and E.D. approved final version of manuscript.

\section{REFERENCES}

1. Andersen CL, Jensen JL, Orntoft TF. Normalization of real-time quantitative reverse transcription-PCR data: a model-based variance estimation approach to identify genes suited for normalization, applied to bladder and colon cancer data sets. Cancer Res 64: 5245-5250, 2004.

2. Angulo J, Mahecha L, Nuernberg K, Nuernberg G, Dannenberger D, Olivera M, Boutinaud M, Leroux C, Albrecht E, Bernard L. Effects of polyunsaturated fatty acids from plant oils and algae on milk fat yield and composition are associated with mammary lipogenic and SREBF1 gene expression. Animal 6: 1961-1972, 2012.

3. Ben Chedly H, Boutinaud M, Bernier-Dodier P, Marnet PG, Lacasse P. Disruption of cell junctions induces apoptosis and reduces synthetic activity in lactating goat mammary gland. J Dairy Sci 93: 2938-2951, 2010.

4. Ben Chedly H, Lacasse P, Marnet PG, Boutinaud M. The decrease in milk yield during once daily milking is due to regulation of synthetic activity rather than apoptosis of mammary epithelial cells in goats. Animal 7: 124-133, 2013.

5. Ben Chedly H, Lacasse P, Marnet PG, Komara M, Marion S, Boutinaud M. Use of milk epithelial cells to study regulation of cell activity and apoptosis during once-daily milking in goats. Animal 5: 572-579, 2011.

6. Ben Chedly H, Lacasse P, Marnet PG, Wiart-Letort S, Finot L, Boutinaud M. Cell junction disruption after $36 \mathrm{~h}$ milk accumulation was associated with changes in mammary secretory tissue activity and dynamics in lactating dairy goats. J Physiol Pharmacol 60, Suppl 3: 105-111, 2009.

7. Benjamini Y, Hochberg Y. Controlling the false discovery rate: a practical and powerful approach to multiple testing. J R Statist Soc B 57: 289-300, 1995.

8. Bionaz M, Loor JJ. Gene networks driving bovine milk fat synthesis during the lactation cycle. BMC Genom 9: 366, 2008.

9. Bionaz M, Loor JJ. Ruminant metabolic systems biology: reconstruction and integration of transcriptome dynamics underlying functional responses of tissues to nutrition and physiological state. Gene Regul Syst Bio 6: $109-125,2012$
10. Boutinaud M, Ben Chedly MH, Delamaire E, Guinard-Flament J. Milking and feed restriction regulate transcripts of mammary epithelial cells purified from milk. J Dairy Sci 91: 988-998, 2008.

11. Boutinaud M, Jammes HN. Growth hormone increases Stat5 and Stat1 expression in lactating goat mammary gland: a specific effect compared to milking frequency. Domest Anim Endocrinol 27: 363-378, 2004.

12. Boutinaud $\mathbf{M}$, Lollivier V, Finot $\mathbf{L}$, Bruckmaier RM, Lacasse $\mathbf{P}$. Mammary cell activity and turnover in dairy cows treated with the prolactin-release inhibitor quinagolide and milked once daily. J Dairy Sci 95: 177-187, 2012.

13. Boutinaud M, Rulquin H, Keisler DH, Djiane J, Jammes H. Use of somatic cells from goat milk for dynamic studies of gene expression in the mammary gland. J Anim Sci 80: 1258-1269, 2002.

14. Boutinaud M, Shand JH, Park MA, Phillips K, Beattie J, Flint DJ, Allan GJ. A quantitative RT-PCR study of the mRNA expression profile of the Igf axis during mammary gland development. J Mol Endocrinol 33: 195-207, 2004.

15. Boutinaud M, Guinard-Flament J, Jammes H. GH and milking frequency act differently on mammary cells. J Animal Feed Sci 13: 467-470, 2004.

16. Camps L, Reina M, Llobera M, Vilaro S, Olivecrona T. Lipoprotein lipase: cellular origin and functional distribution. Am J Physiol Cell Physiol 258: C673-C681, 1990.

17. Connelly L, Barham W, Pigg R, Saint-Jean L, Sherrill T, Cheng DS, Chodosh LA, Blackwell TS, Yull FE. Activation of nuclear factor kappa $\mathrm{B}$ in mammary epithelium promotes milk loss during mammary development and infection. J Cell Physiol 222: 73-81, 2010.

18. Connor EE, Siferd S, Elsasser TH, Evock-Clover CM, Van Tassell CP, Sonstegard TS, Fernandes VM, Capuco AV. Effects of increased milking frequency on gene expression in the bovine mammary gland. BMC Genom 9: 362, 2008.

19. Darcy KM, Zangani D, Wohlhueter AL, Huang RY, Vaughan MM, Russell JA, Ip MM. Changes in ErbB2 (her-2/neu), ErbB3, and ErbB4 during growth, differentiation, and apoptosis of normal rat mammary epithelial cells. J Histochem Cytochem 48: 63-80, 2000.

20. Davis SR, Farr VC, Stelwagen K. Regulation of yield loss and milk composition during once-daily milking: a review. Livestock Prod Sci 59: 77-94, 1999.

21. Delmar P, Robin S, Daudin JJ. VarMixt: efficient variance modelling for the differential analysis of replicated gene expression data. Bioinformatics 21: 502-508, 2005.

22. Farke C, Meyer HHD, Bruckmaier RM, Albrecht C. Differential expression of $\mathrm{ABC}$ transporters and their regulatory genes during lactation and dry period in bovine mammary tissue. J Dairy Res 75: 406-414, 2008.

23. Favier J, Lapointe S, Maliba R, Sirois MG. HIF2 alpha reduces growth rate but promotes angiogenesis in a mouse model of neuroblastoma. BMC Cancer 7: 139, 2007.

24. Flint DJ, Boutinaud M, Tonner E, Wilde CJ, Hurley W, Accorsi PA, Kolb AF, Whitelaw CB, Beattie J, Allan GJ. Insulin-like growth factor binding proteins initiate cell death and extracellular matrix remodeling in the mammary gland. Domest Anim Endocrinol 29: 274-282, 2005.

25. Hayashi AA, McCoard SA, Roy NC, Barnett MPG, MacKenzie DDS, McNabb WC. Gene expression in bovine mammary somatic cells isolated from milk. J Anim Feed Sci 13, Suppl 1: 401-404, 2004.

26. Heid HW, Moll R, Schwetlick I, Rackwitz HR, Keenan TW. Adipophilin is a specific marker of lipid accumulation in diverse cell types and diseases. Cell Tissue Res 294: 309-321, 1998.

27. Jackson-Fisher AJ, Bellinger G, Breindel JL, Tavassoli FA, Booth CJ, Duong JK, Stern DF. ErbB3 is required for ductal morphogenesis in the mouse mammary gland. Breast Cancer Res 10: R96, 2008.

28. Kendrick H, Regan JL, Magnay FA, Grigoriadis A, Mitsopoulos C, Zvelebil M, Smalley MJ. Transcriptome analysis of mammary epithelial subpopulations identifies novel determinants of lineage commitment and cell fate. BMC Genomics 9: 591, 2008.

29. Knight CH, Peaker M, Wilde CJ. Local control of mammary development and function. Rev Reprod 3: 104-112, 1998.

30. Koprowski JA, Tucker HA. Serum prolactin during various physiological states and its relationship to milk production in the bovine. Endocrinology 92: 1480-1487, 1973.

31. Lacasse P, Lollivier V, Bruckmaier RM, Boisclair YR, Wagner GF, Boutinaud M. Effect of the prolactin-release inhibitor quinagolide on lactating dairy cows. J Dairy Sci 94: 1302-1309, 2011. 
32. Lacy-Hulbert SJ, Woolford MW, Nicholas GD, Prosser CG, Stelwagen K. Effect of milking frequency and pasture intake on milk yield and composition of late lactation cows. J Dairy Sci 82: 1232-1239, 1999.

33. Li P, Rudland PS, Fernig DG, Finch LMB, Wilde CJ. Modulation of mammary development and programmed cell death by the frequency of milk removal in lactating goats. J Physiol 519: 885-900, 1999.

34. Littlejohn MD, Walker CG, Ward HE, Lehnert KB, Snell RG, Verkerk GA, Spelman RJ, Clark DA, Davis SR. Effects of reduced frequency of milk removal on gene expression in the bovine mammary gland. Physiol Genomics 41: 21-32, 2010.

35. Marnet PG, Komara M. Management systems with extended milking intervals in ruminants: Regulation of production and quality of milk. $J$ Anim Sci 86: 47-56, 2008.

36. Murrieta CM, Hess BW, Scholljegerdes EJ, Engle TE, Hossner KL, Moss GE, Rule DC. Evaluation of milk somatic cells as a source of mRNA for study of lipogenesis in the mammary gland of lactating beef cows supplemented with dietary high-linoleate safflower seeds. J Anim Sci 84: 2399-2405, 2006

37. Naylor MJ, Oakes SR, Gardiner-Garden M, Harris J, Blazek K, Ho TWC, Li FC, Wynick D, Walker AM, Ormandy CJ. Transcriptional changes underlying the secretory activation phase of mammary gland development. Mol Endocrinol 19: 1868-1883, 2005.

38. O'Brien B, Ryan G, Meaney WJ, McDonagh D, Kelly A. Effect of frequency of milking on yield, composition and processing quality of milk. J Dairy Res 69: 367-374, 2002.

39. Paul A, Chang BH, Li L, Yechoor VK, Chan L. Deficiency of adipose differentiation-related protein impairs foam cell formation and protects against atherosclerosis. Circ Res 102: 1492-1501, 2008.

40. Pfaffl MW, Tichopad A, Prgomet C, Neuvians TP. Determination of stable housekeeping genes, differentially regulated target genes and sample integrity: BestKeeper-Excel-based tool using pair-wise correlations. Biotechnol Lett 26: 509-515, 2004.

41. Piantoni P, Wang P, Drackley JK, Hurley WL, Loor JJ. Expression of metabolic, tissue remodeling, oxidative stress, and inflammatory pathways in mammary tissue during involution in lactating dairy cows. Bioinform Biol Insights 4: 85-97, 2010.

42. Pullan S, Wilson J, Metcalfe A, Edwards GM, Goberdhan N, Tilly J, Hickman JA, Dive C, Streuli CH. Requirement of basement membrane for the suppression of programmed cell death in mammary epithelium. $J$ Cell Sci 109: 631-642, 1996.

43. Quarrie LH, Addey CVP, Wilde CJ. Local regulation of mammary apoptosis in the lactating goat. Biochem Soc Transact 22: S178, 1994.

44. Rabot A, Sinowatz F, Berisha B, Meyer HH, Schams D. Expression and localization of extracellular matrix-degrading proteinases and their inhibitors in the bovine mammary gland during development, function, and involution. J Dairy Sci 90: 740-748, 2007.

45. Remond B, Aubailly S, Chilliard Y, Dupont D, Pomies D, Petit M. Combined effects of once-daily milking and feeding level in the first three weeks of lactation on milk production and enzyme activities, and nutritional status, in Holstein cows. Anim Res 51: 101-117, 2002.

46. Schedin P, Strange R, Mitrenga T, Wolfe P, Kaeck M. Fibronectin fragments induce MMP activity in mouse mammary epithelial cells: evidence for a role in mammary tissue remodeling. J Cell Sci 113: 795-806, 2000.

47. Singh K, Davis SR, Dobson JM, Molenaar AJ, Wheeler TT, Prosser CG, Farr VC, Oden K, Swanson KM, Phyn CVC, Hyndman DL, Wilson T, Henderson HV, Stelwagen K. cDNA microarray analysis reveals that antioxidant and immune genes are upregulated during involution of the bovine mammary gland. J Dairy Sci 91: 2236-2246, 2008.

48. Smyth GK, Speed T. Normalization of cDNA microarray data. Methods 31: 265-273, 2003.

49. Stein T, Salomonis N, Gusterson BA. Mammary gland involution as a multi-step process. J Mamm Gland Biol Neoplas 12: 25-35, 2007.

50. Suzuki S, Takagi K, Miki Y, Onodera Y, Akahira J, Ebata A, Ishida T, Watanabe M, Sasano H, Suzuki T. Nucleobindin 2 in human breast carcinoma as a potent prognostic factor. Cancer Sci 103: 136-143, 2012.

51. Thering BJ, Graugnard DE, Piantoni P, Loor JJ. Adipose tissue lipogenic gene networks due to lipid feeding and milk fat depression in lactating cows. J Dairy Sci 92: 4290-4300, 2009.

52. Vandesompele J, De Preter K, Pattyn F, Poppe B, Van Roy N, De Paepe A, Speleman F. Accurate normalization of real-time quantitative RT-PCR data by geometric averaging of multiple internal control genes. Genome Biol 3: 0034.1, 2002.

53. Wall EH, Crawford HM, Ellis SE, Dahl GE, McFadden TB. Mammary response to exogenous prolactin or frequent milking during early lactation in dairy cows. J Dairy Sci 89: 4640-4648, 2006.

54. Wall EH, McFadden TB. Triennial lactation symposium: a local affair: how the mammary gland adapts to changes in milking frequency. $J$ Anim Sci 90: 1695-1707, 2012.

55. Williams CM, Engler AJ, Slone RD, Galante LL, Schwarzbauer JE. Fibronectin expression modulates mammary epithelial cell proliferation during acinar differentiation. Cancer Res 68: 3185-3192, 2008.

56. Wu AM, Dalvi P, Lu X, Yang M, Riddick DS, Matthews J, Clevenger CV, Ross DD, Harper PA, Ito S. Induction of multidrug resistance transporter ABCG2 by prolactin in human breast cancer cells. Mol Pharmacol 83: 377-388, 2013.

57. Yang S, Kim J, Ryu JH, Oh H, Chun CH, Kim BJ, Min BH, Chun JS. Hypoxia-inducible factor-2alpha is a catabolic regulator of osteoarthritic cartilage destruction. Nat Med 16: 687-693, 2010.

58. Yang YH, Dudoit S, Luu P, Lin DM, Peng V, Ngai J, Speed TP. Normalization for cDNA microarray data: a robust composite method addressing single and multiple slide systematic variation. Nucl Acids Res 30: e15, 2002.

59. Yu TC, Chen SE, Ho TH, Peh HC, Liu WB, Tiantong A, Nagahata H, Chang CJ. Involvement of TNF-alpha and MAPK pathway in the intramammary MMP-9 release via degranulation of cow neutrophils during acute mammary gland involution. Vet Immunol Immunopathol 147: 161$169,2012$.

60. Zamora C, Canto E, Nieto JC, Angels Ortiz M, Juarez C, Vidal S. Functional consequences of CD36 downregulation by TLR signals. Cytokine 60: 257-265, 2012

61. Zibara K, Malaud E, McGregor JL. CD36 mRNA and protein expression levels are significantly increased in the heart and testis of apoE deficient mice in comparison to wild type (C57BL/6). J Biomed Biotechnol 2: 14-21, 2002. 